\title{
POLITICAL BUSINESS CYCLE \\ IN THE CZECH REPUBLIC: \\ CASE OF MUNICIPALITIES
}

\section{Michal Plaček, Milan Půček, František Ochrana, Milan Křápek, Lenka Matějová*}

\begin{abstract}
:
The study analyses expenditures of all municipalities of the Czech Republic over the period 2003-2013. It aims to examine whether changes in municipal spending get affected by the electoral cycle. The analysis has proven that expenditures of municipalities of the Czech Republic are influenced by the political cycle. However, the political business cycle has at the level of municipalities (compared to the macroeconomic level) its peculiarities. These arise mainly from limited options of municipal politicians to use economic instruments to win electoral votes in elections. To receive electoral votes, municipal politicians use mainly public investments and projects that are at the level of municipalities so apparent that they may influence voters in their electoral decision-making. Prior to elections, expenditures on investments significantly increase for all municipal size groups. For municipal size groups of over 50,000 residents, however, they are (per capita) higher compared to smaller municipal size groups. This may be explained by the fact that these municipalities have higher disposable resources (higher per capita own budgetary revenues, higher potential to acquire resources to co-finance municipal projects and broader portfolio of debt financing). Expenditures on transfers do not significantly change prior to municipal elections. We interpret this finding in a way that politicians prefer such investment projects that are "visible". Transfers are used to pay for certain current expenses for which municipalities may (in accordance with the established rules) apply through grants.
\end{abstract}

Keywords: political business cycle, political business cycle at the level of municipalities in the Czech Republic, investment expenditures, transfers

JEL Classification: H57, G14

\section{Introduction}

Activity of politicians on the political market (Downs, 1998) gets influenced by a number of factors (Alesina and Roubini, 1992). One of them is the rational motive of politicians to get re-elected in elections. Towards this end, politicians (governments) use economic instruments in order to win on their side voters in elections. The theory of the political business cycle deals with a theoretical explanation of this issue. This theory conceives politicians as rationally behaving actors who act on the political market so as to influence

* Michal Plaček, Faculty of Social Sciences, Charles University, Prague (michalplacek@seznam.cz);

Milan Půček, Faculty of Social Sciences, Charles University, Prague (milan.pucek@seznam.cz);

František Ochrana, Faculty of Social Sciences, Charles University, Prague (ochrana@fsv.cuni.cz);

Milan Křápek, Private College of Economic Studies, Znojmo (krapek@svse.cz);

Lenka Matějová, Faculty of Economics and Administration, Masaryk University, Brno

(175001@mail.muni.cz).

This article is a result of the Project P-17 "Science of a Society, Politics and Media within

Challenges of the Time" by Faculty of Social Sciences, Charles University in Prague. 
the decision-making of voters in their favour. Models assume that politicians (same as agents on the political market) have their utility function with parameters they attempt to maximise. The aim of politicians is thus to increase the likelihood of their re-election. This manipulation of politicians with the electorate is built into the political business cycle models in that voters vote on the basis of economic variables.

Since the length of the political election cycle is (as opposed to the economic cycle) known, politicians (governments) may with respect to the given length of an election term project within individual stages of the electoral cycle their objectives and implement their activities.

Manipulation of politicians with economic instruments is caused by an effort to implement positive measures towards the date of elections, when politicians by their measures appeal to voters with the aim to win their votes. Following the elections, politicians usually deal with unpopular issues associated with the effects of previous decisions (Slaný a Žák, 1999).

These activities, spread out into the individual phases of the electoral cycle (prior to elections, within the first half of the electoral cycle and within the second half of the electoral cycle with the prospect of upcoming elections) may be empirically recorded through changes in economic indicators (employment, public expenditures, budget deficit, GDP growth and inflation). A theoretical reflection of this issue provides the political business cycle theory. The theory of the political business cycle almost invariably focuses on the analysis of macroeconomic impacts of political decisions of the central government. Therefore, there emerges a question whether it is possible to register the existence of the political business cycle at the level of municipal governments. The aim of this study is to examine expenditures of municipalities of the Czech Republic (carried out over the period 2003-2012), i.e. whether changes in expenditures are affected by the electoral cycle, to test the related hypotheses and from the executed analysis to draw theoretical conclusions.

\section{Research Foundations}

With the idea of the political business cycle comes Nordhaus (1975) and subsequently also Lindbeck (1976) and McRae (1977). The model by Nordhaus assumes opportunistic parties and irrational voters. Within the first stage of the political business cycle, the government carries out a deliberate pre-election expansion. Its consequences are a reduction in unemployment, GDP growth, but also an increase in inflation. Towards "taming"of inflation and other unpopular actions it gets within the second stage of the political business cycle, characterised by a restriction. The government directs unpopular measures into the first half of the post-election period. Because voters are irrational ("forgetful" and "incorrigible"), the government may repeat the entire procedure again prior to next elections.

With a different view on the political business cycle comes Hibbs (1977). In the model by Hibbs, political parties stand out as actors who profess various ideologies and therefore also address "their groups" of voters. Voters are rational actors who within the political market (Downs, 1998) choose the appropriate political party whose political ideology the most accurately reflects their voting preferences.

If we for the sake of simplification assume a right-left political spectrum, then the right-wing government prefers low inflation, higher unemployment and lower redistribution of the generated GDP through public expenditures while the left-wing government gives its priority to higher employment rates, higher rate of inflation and higher degree 
of redistribution through public spending. Leftist, respectively right-wing voters in turn (with regard to their respective ideology) vote for the relevant political party.

Both mentioned models soon found their followers and elaborators. Already in the 1980s there emerges a new generation of models based on the idea of rational expectations. With a rational opportunistic model come Rogoff and Sibert (1988). Because voters are rational, the government cannot positively affect real variables (Rogoff, 1990). Provided the government undertakes prior to elections an expansionary fiscal policy, the result is only increased inflation. Efforts of opportunistic political parties to win over an ideological voter are thus misguided.

With a rationally ideological model come Alesina (1987), Alesina and Sachs (1986). This model is based on the assumption of a rationally behaving voter and a political party governed by its own ideology. If we assume a left-right political spectrum, then the leftwing party will just prior to elections carry out an expansionary economic policy in order to achieve a higher level of employment and GDP growth. However, the consequence of an expansion is also a growth of inflation. Because voters are rational actors, there comes to changes in employment only for a short period of time since voters adapt to the given changes. The ultimate effect of the leftist politics is a growth in inflation.

With different objectives comes ahead of elections the right-wing political party. Its priority objective is to reduce inflation. However, the government may achieve this objective only for a short period of time since within the next period this goal will be prevented by rational expectations of voters.

As clear from the brief overview of the political business cycle models, the given models are linked by an identical conclusion that politicians seek to influence the outcome of elections through instruments of fiscal policy (especially via public expenditures, reflected in the budget deficit). Contemporary panel empirical research (see e.g. Shi and Svenson, 2006; Drazen, 2001; Persson and Tabellini, 2003) proves is considered the existence of the political business cycle. Its existence also by Brender and Drazen (2005) in the case of the so-called new democracies which include also the Czech Republic. Brender and Drazen point out that the political business cycle may also be shrouded by manipulations of politicians with shifting of public expenditures so that at a first glance the manipulation of politicians with the economy may not be apparent.

Also in the Czech Republic we find studies that on data of the Czech Republic examine the policy-economic cycle (see e.g. Žák, 1998; Janků, 2013) or deal with the political legislation cycle (Brechler and Geršl, 2011), namely test models of the political business cycle in conditions of the Czech Republic (Štiková, 2007). An analysis of these studies leads to the conclusion that in the Czech Republic there may be also from the economic impacts of political decisions of the central government inferred an existence of the political business cycle.

With regard to examination of the political business cycle at the level of municipalities, there is only a modest number of studies dealing with that issue. Sedmihradská, Haas and Kubík examine on the case of 205 municipalities of the Czech Republic (over the period 2001-2007) the relationship between an electoral year and capital expenditures. The research findings confirm existence of the political business cycle and opportunistic behaviour of politicians. The study by Portuguese authors Veiga and Veiga (2007) comes with a different approach. Authors of the study examine changes in municipal investment expenditures prior to elections. These are such expenditures that are on the part of an electorate clearly visible. Voters in their municipalities certainly discern such investments 
as constructions or repairs of roads, repairs of churches or schools. In such a case tempering with expenditures is carried out through changes in the structure of expenditures. Within the election year thus there increases the share of capital expenditures channelled towards "visible investment projects".

With a different concept comes Rosenberg (1992). He assumes the case where a rational politician does not seek his/her re-election but through the implemented and arranged projects prepares his/her position following the end of the election period when a politician passes over to the commercial sphere. In the Czech Republic it is possible to record similar cases for which we use the term "politics as an elevator to the business sector". The given citizen becomes a politician in order to take advantage of politics as a means of his/her preparation for the successful entry into the business sector. This type of a politician does not seek his/her re-election for another voting term. However, during the regular voting term he/she arranges and approves projects that within rigged contests get awarded to friendly or otherwise close firms. Such cases are usually associated with the corruption in public procurement (Pavel, 2013; Vlach, Nemec, 2001). We may also record cases when the position of the leaving politician is upon the new election term taken over by a person that is close to him/her and whose entry into politics the outgoing politician supported. Also these are known cases from the municipal politics of the Czech Republic. It considers politicians with a "seat reservation" for an entry into politics.

From the analysis of studies dealing with the political business cycle it is possible to draw the following general conclusions. Although political business cycle models differ in their theoretical fundaments, they are linked by the same ontology - that is, the real existence of the political business cycle. The reality of the political business cycle is theoretically examined from different perspectives. This difference is reflected in plurality of political business cycle models. Because these models in principle portray the same reality, we can find a common structural assumption of the political business cycle models - in that the voters vote on the basis of economic variables while this choice is influenced by the deliberate activity of politicians oriented towards swaying the voter. This deliberate activity of politicians takes the form of governmental measures that affect economic performance, unemployment and inflation.

At the central level there are thus governmental activities within the first cycle (i.e. prior to elections) characterised by an expansive fiscal policy and fiscal pre-election manipulations, when through boosted public spending there comes to a one-off deflection of the state budget deficit. In case within the second cycle (i.e. following the elections) the economy finds itself due to an economic expansion above its potential GDP, inflation increases. To resolve this issue the government adopts a restrictive policy. These unpopular measures the government adopts within the first period of its voting term. This fact is within the political business cycle models depicted as a decrease in public expenditures, decline in employment and reduced inflation. Although these given theoretical conclusions relate to the macroeconomic level, some are inspiring for the design of a theoretical framework for research of the political business cycle also at the level of municipalities.

Also at the municipal level there may be assumed an existence of the political business cycle. It is characterised by some common features with the political business cycle at the macro level while at the same time it differs. A municipal politician has a similar goal as a politician of the central government - i.e. to get re-elected. The rationality of a municipal politician may, however, manifests itself also through maximising of the personal benefit of already non-standing political candidates. This relates to the cases known from local 
politics in the Czech Republic where municipal politics is treated as a means (an elevator) of a politician into the business (commercial) sector.

Another difference of a municipal politician from a politician of the central government rests in the different extent of options to temper with economic tools. This difference is given by the type of a fiscal federalism adopted by different countries. In the centralised model, local government budgets are fully dependent upon grants channelled from the central government. Politicians therefore have a very limited opportunity to move with taxes and they may influence rather expenditures. In contrast, within the decentralised model individual municipalities may secure their own revenues through the setting of local taxes and charges. In reality a fully centralised or decentralised model occurs rarely and adopted is rather a mixed model where local governments receive grants from the central government; there comes to a redistribution of income through the budgetary allocation of tax revenues while local governments may, to a limited extent, also set their local taxes and charges.

Legislative rules do not provide municipal politicians with such a room for the use of economic instruments towards pre-election manipulation. In the Czech Republic, municipal politicians have only a very limited opportunity to influence their tax and non-tax revenues. This is (in contrast to central government politicians) a significant restriction on the side of municipal budgetary revenues. The main revenues represent shared taxes, distributed in accordance to the Act on Budgetary Allocation of Tax Revenues. Municipalities may further determine through local ordinances the coefficient of the tax on immovable property and set the level of local charges which, nevertheless, may not exceed limits set by the law. Revenues from the tax on immovable property and local charges represent, depending on the characteristics of the given municipality, a volume corresponding to $c a$. single digit percentage points of the total budget. Another possibility of municipalities how to boost their revenues is a sale and privatisation of the municipal property. Last but not least, there are other ways of how to increase the revenue side of the municipal budget - discretionary grants (e.g. from the EU funds or national grants). A number of mayors focus a great deal of attention in particular to discretionary grants and also with this theme they operate prior to elections (i.e. either factual or just declared ability to secure grants for the municipality should act as an attraction to voters). These ways are limited also the possibilities of municipal politicians on the part of budgetary expenditures. Municipalities are required to provide certain public services. An increase in expenditures on these services within the pre-election year (e.g. due to the rising costs of higher quality services) could be indicative of an attempt of politicians to influence the decision-making of voters in elections.

Municipalities carry out current and capital expenditures. Into current expenditures there may be included also non-investment transfers. These are non-equivalent payments to private natural and legal entities and non-profit organisations. In this way there is most frequently sponsored sport, culture, civil societies and education at the local level. Although municipalities often state that grants are distributed based on objective grant schemes, in reality the decision on where the money "will travel" rests in the last instance on councillors and representatives. This means that investment transfers provide a relatively large scope for addressing relatively homogeneous and organised constituencies from the side of politicians.

Public investments provide a relatively broad range of possibilities towards swaying voters prior to elections. Local politicians have an immediate opportunity to influence which investments (public projects) shall be within the given municipality implemented. 
Public projects are so clearly visible that the residents themselves mark such implemented projects as "memorials of politicians". Politicians are aware of this fact. They know that "their monument" may affect decision-making of voters in elections. Voters likely perceive this fact positively even when the municipality borrows (using e.g. the form of a credit) the necessary resources needed to implement the given project. It is therefore to be expected that within the pre-election period there will be a higher deficit of municipal budgets compared to the post-election period. A deficit therefore arises in a situation where expenditures of a municipality are higher that its revenue. The resulting deficit may be covered either via repayable financial assistance in the form of loans or issued bonds or via surpluses from previous years. For a citizen it is somewhat difficult to identify the manner in which the deficit is covered. Moreover, within officially published budgets revenues and expenditures are always balanced; the difference between revenues and expenditures makes up an item called financing (funding). If this item is positive, we find ourselves in a situation where revenues are less than expenditures, the budget is therefore in deficit. If this item is negative, revenues are larger than expenditures and the budget is in surplus.

Although public projects may be co-financed from the EU funds, voters assess this fact as a "positive act of local politicians" who managed to get those resources. Also this act of politicians influences the decision-making of voters in elections because rational (informed) voters are able to distinguish that obtaining financial resources from the EU funds (as opposed to transfers resulting from higher budgets) is due to local politicians (e.g. as they elaborated a successful grant application).

At the municipal level, we may distinguish two kinds of voters. The first group is represented by rational voters who have enough experience with activities of municipal politicians from the previous electoral period and who also possess sufficient information to rationally decide within their choice of politicians. Voters at the municipal level have a relatively easier access to information about politicians. They frequently know them personally and they are also aware of their work from the previous electoral period and connections to other actors. Therefore we believe that voters on the municipal level vote more for personalities than for political parties. Municipal voters are thus more pragmatic in their choice of politicians.

In this context it is possible to voice an assumption that at the level of municipalities, the political ideology does not play such an important role in the choice of politicians as at the central level. At the same time it is reasonable to assume that there exists an inverse relationship between the preference of voting for a personality and the municipality size (number of voters or residents, respectively) in a sense that the smaller the municipality, the more voters know local politicians and the more they in their choices tend to select politicians based on their personal knowledge of politicians rather than on the basis of an affiliation to a political party. This hypothesis, however, does not stand as a research subject of this study. Due to the absence of necessary data, its verification would require an independent stand-alone research.

Also at the level of municipalities we encounter irrational voters. These are both inexperienced voters as well as "forgetful" voters who forget actions of politicians from the previous electoral term. We believe that the share of inexperienced voters (in relation to the total number of voters) is at the municipality level lower than the proportion of inexperienced voters to the total number of voters who choose their representatives in central authorities. 


\section{Hypotheses, Research Methods and Research Procedure}

In the context of the theoretical background we aim to investigate the following hypotheses (Table 1).

Table 1 | Hypotheses

\begin{tabular}{|l|l|}
\hline Hypothesis $H_{i}$ & \multicolumn{1}{c|}{ Wording of the Hypothesis } \\
\hline$H_{1}$ & $\begin{array}{l}\text { Within the pre-election year there does not come to any significant changes } \\
\text { in the volume of transfers. }\end{array}$ \\
\hline $\boldsymbol{H}_{2}$ & $\begin{array}{l}\text { Within the pre-election year there comes to a significant increase in expenditures } \\
\text { on public investments and municipal projects. }\end{array}$ \\
\hline $\boldsymbol{H}_{3}$ & $\begin{array}{l}\text { The amount of expenditures on transfers, public investments and municipal } \\
\text { projects (reference period is the pre-election year and criterion are per capita } \\
\text { expenditures in the given size category of a municipality) does not significantly } \\
\text { depend on the size of a municipality. }\end{array}$ \\
\hline
\end{tabular}

Methods adopted for verification of individual hypotheses are described in more detail within the section "Data Collection and Research Procedure".

In order to test the hypotheses, we analysed expenditures of all municipalities of the Czech Republic over the period 2003-2012. From the data set there were examined municipal expenditures on transfers and investments. These are such types of expenditures through which it is possible to examine the validity of the theoretical backgrounds and test the hypotheses.

To investigate the relationship between expenditures and the size of a municipality in the per capita form, there were adopted the following size categories of municipalities (Table 2).

Table 2 | Distribution of Surveyed Municipalities of the Czech Republic by Size Category

\begin{tabular}{|c|c|}
\hline Size category of a municipality (number) & Number of residents in given size category \\
\hline $\mathbf{1}$ & $0-100$ \\
\hline $\mathbf{2}$ & $101-200$ \\
\hline $\mathbf{3}$ & $201-500$ \\
\hline $\mathbf{4}$ & $501-1,000$ \\
\hline $\mathbf{5}$ & $1,001-2,000$ \\
\hline $\mathbf{6}$ & $2,001-5,000$ \\
\hline $\mathbf{7}$ & $5,001-10,000$ \\
\hline $\mathbf{8}$ & $10,001-20,000$ \\
\hline $\mathbf{9}$ & $20,001-50,000$ \\
\hline $\mathbf{1 0}$ & $50,001-100,000$ \\
\hline $\mathbf{1 1}$ & $100,001-1,000,000$ \\
\hline $\mathbf{1 2}$ & over $1,000,000$ \\
\hline
\end{tabular}


The given classification of municipalities allows examining the impact of decentralisation on the existence of the political cycle for municipalities of the Czech Republic and to check what impact on municipal public spending (transfers, public investments and municipal projects) within the pre-election year has the size of a municipality. A similar question posed in their study Sedmihradská, Haas and Kubík (2007). Their investigation, however, included an analysis of all 205 municipalities with an extended scope of authority over the period 2001-2007. We agree on that per capita capital expenditures are significantly higher within the pre-election and election year, but we are of an opinion that per capita capital expenditures are not dependent upon the size of a municipality. Our research (unlike the aforementioned study by Sedmihradská, Haas and Kubík) includes all municipalities of the Czech Republic and all size categories. We believe that the size of investment expenditures within the pre-election year (per capita) does not substantially depend upon the size of a municipality.

\section{Data collection and research procedure}

The required data on municipal expenditures and their structure were obtained from the Ministry of Finance of the Czech Republic through the Union of Towns and Municipalities of the Czech Republic. The research procedure was implemented in the following steps:

1. Acquired data were adjusted for inflation using the GDP deflator. Data on expenditures over the monitored period were recalculated to the base year 2003.

2. Data were divided into 12 groups according to the size of a municipality, for each group we have 10 annual data on costs of transfers and investments. Without any loss of generality we may label both types of data identically. The data are therefore labelled cost $_{i j}$, where $i \in\{1,2, \ldots, 12\}$ indicates the group to which the given data belong and the index $\mathrm{j}$ in turn indicates the year while there applies that $\mathrm{j} \in\{1,2, \ldots, 10\}$.

3. Due to the representative comparison of expenditures in individual municipal size categories were costs cost ${ }_{i j}$ recalculated into costs per resident. Let us denote res the number of residents in the $\mathrm{i}$-th group. Then we get the value $\operatorname{costres}_{i j}=\operatorname{cost}_{i j} /$ res $_{i}$.

4. From such adjusted costs there were determined time moving averages that are always based on three consecutive years. Provided we denote these moving averages $\bar{x}_{i j}$, then it applies $\bar{x}_{i j}=\frac{\text { costres }_{i j-1}+\operatorname{costres}_{i j}+\operatorname{costres}_{i j+1}}{3}$ for $\mathrm{i} \in\{1,2, \ldots, 12\}$ and $\mathrm{j} \in\{2,3, \ldots, 9\}$.

Extreme moving averages were determined by dual use of an extreme value, i.e. $\bar{x}_{i 1}=\frac{2 \cdot \operatorname{costres}_{i 1}+\operatorname{costres}_{i 2}}{3}$ and $\bar{x}_{i 10}=\frac{\operatorname{costres}_{i 9}+2 \cdot \operatorname{costres}_{i 10}}{3}$.

5. For analysis of the dynamics of expenditures on transfers and public investments we operate with differences in absolute values of expenditures in individual years recalculated per one resident and with differences in the three-year moving average. These differences were labelled as difcost $t_{i j}$ and it applies for them that $\operatorname{difcost}_{i j}=$ costres $_{i j}-\bar{x}_{i j}$.

6. Time series 2003-2013 was split into the election and non-election years. For election years, the parameter elect t takes the value of 1 while non-election years assume for this parameter the value of 0 . 
7. From the above values there were determined dependencies of differences in expenditures on transfers and public investments on whether there did or did not take place elections. There was verified a dependency of whether the size of a municipality has within the election period any effect on the change in municipal expenditures (per capita) outlaid on transfers and public investments.

8. There was carried out a correlation analysis of dependencies between differences in costs per resident difcost $t_{i j}$, both expenditures on transfers and expenditures on investments with the parameter elect ${ }_{j}$ and the size of a municipality given by the parameter $i$. The calculation of a correlation coefficient $\mathrm{r}$ was carried out using the formula $r=\frac{\sum_{i=1}^{n}\left(x_{i}-\bar{x}\right)\left(y_{i}-\bar{y}\right)}{\sqrt{\sum_{i=1}^{n}\left(x_{i}-\bar{x}\right)^{2} \sum_{i=1}^{n}\left(y_{i}-\bar{y}\right)^{2}}}$, where in place of the random variables $x$ and $y$ we substituted different pairs of variables.

9. In case there was detected a significant dependency, we subsequently performed a regression analysis and searched for a suitable model that would best explain the examined reality using the adjusted coefficient of determination (Novotná - Varyšová, 2014). Adopted regression models are

a. Linear difcost $=a+b \cdot$ elect

b. Quadratic difcost $=a+b \cdot$ elect $+c \cdot$ elect $t^{2}$

c. Exponential difcost $=a+b \cdot e^{\text {elect }}$

\section{Research Results and Discussion}

To verify changes in the volume of transfers $\left(H_{l}\right)$ and changes in the volume of investments $\left(\mathrm{H}_{2}\right)$ there were used indicators of average differences in expenditures on transfers and investments according to the election and non-election years. These differences (using a moving average) are recalculated to the per capita basis. Final calculations are shown in Table 3.

Table 3 | Average Difference in Investments and Transfers (in election and non-election years)

\begin{tabular}{|l|c|c|}
\hline \multirow{2}{*}{$\begin{array}{l}\text { Monitored data } \\
\text { (period 2003-2012) }\end{array}$} & \multicolumn{2}{|c|}{ Elections } \\
\cline { 2 - 3 } & $\mathbf{0}$ & $\mathbf{1}$ \\
\hline Average from the difference in investments & -0.09362 & 0.371336 \\
\hline Average from the difference in transfers & -0.01373 & 0.053869 \\
\hline
\end{tabular}

Source: own calculations

Values in Table 3 give average values of the variable difcost $t_{i j}$ Provided we divide the table into two groups according to election and non-election years, into the election years belongs data with indices $i=4$ and $i=8$ (corresponding to the years 2006 and 2010) while the remaining belong to the non-election years. 
Results of the analysis cover the period 2003-2012 and relate to the expenditures on transfers and investments for all municipalities of the Czech Republic.

As evident from the data, regarding transfers we recorded in election years there are only very small changes. This empirical finding is consistent with theoretical assumptions stated within research foundations. We may therefore observe that municipal politicians do not use transfers as a tool for influencing voters. That is also why there does not come to any substantial changes in expenditures on transfers within election and non-election years. The trend in development of transfers (period 2003-2012) are shown Figure 1.

Figure 1 | Transfers per Resident (2003-2012)

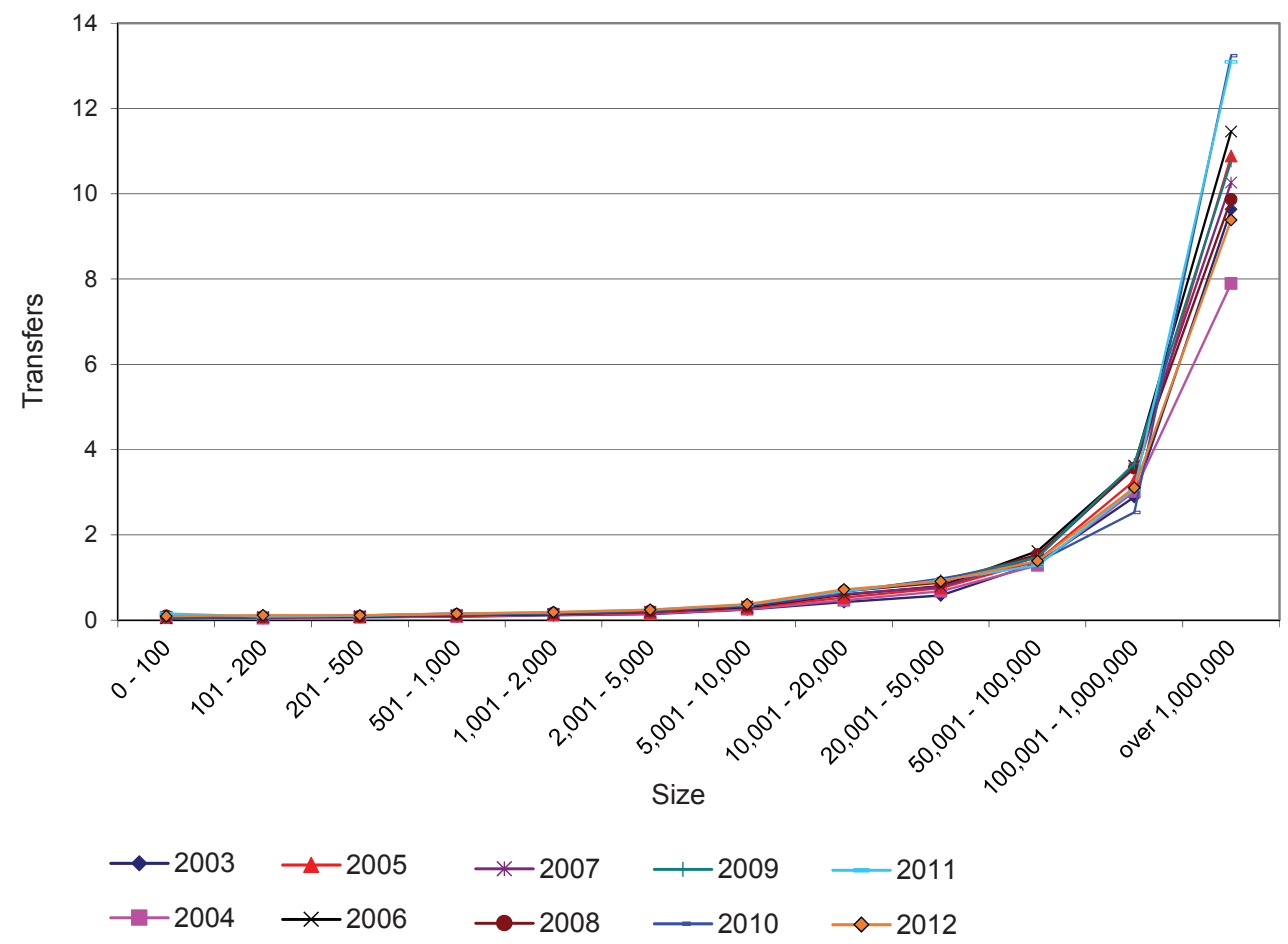

Source: authors

From the above figure it is clear that the volume of expenditures on transfers (per capita) demonstrates for all size categories of municipalities persistence whereas there does not come to any significant difference depending on the election and non-election years. This finding is consistent with the theoretical foundations and confirms the hypothesis $H_{1}$. As another interpretation comes forward the long-term fixation of transfers to current municipality revenues.

However, if we examine the level of expenditures on transfers (per capita) over the time series 2003-2012 we find out that expenditures in all years demonstrate for all size categories of municipalities a certain persistence, however, the municipality size categories 11 and 12 (i.e. towns with over 100,000 residents) carry out significantly higher transfers 
(per capita). This is given mainly due to the budgetary allocation of tax revenues and for the City of Prague (the only town in the Czech Republic with the population of over 1 million residents) also due to the fact that it performs the function of both a municipality and a region. However, overall it applies that the size of a municipality does not have any significant effect on the difference in the volume of transfers within election and nonelection years.

\section{Investments}

If we follow the municipal expenditures on investments over the period 2003-2012, we note that staring from municipal categories of over 50,000 residents and above, expenditures on investments (per capita) are clearly higher compared to smaller size categories (see Figure 2).

Figure 2 | Expenditures of Municipalities on Investments (per capita) in 2003-2012

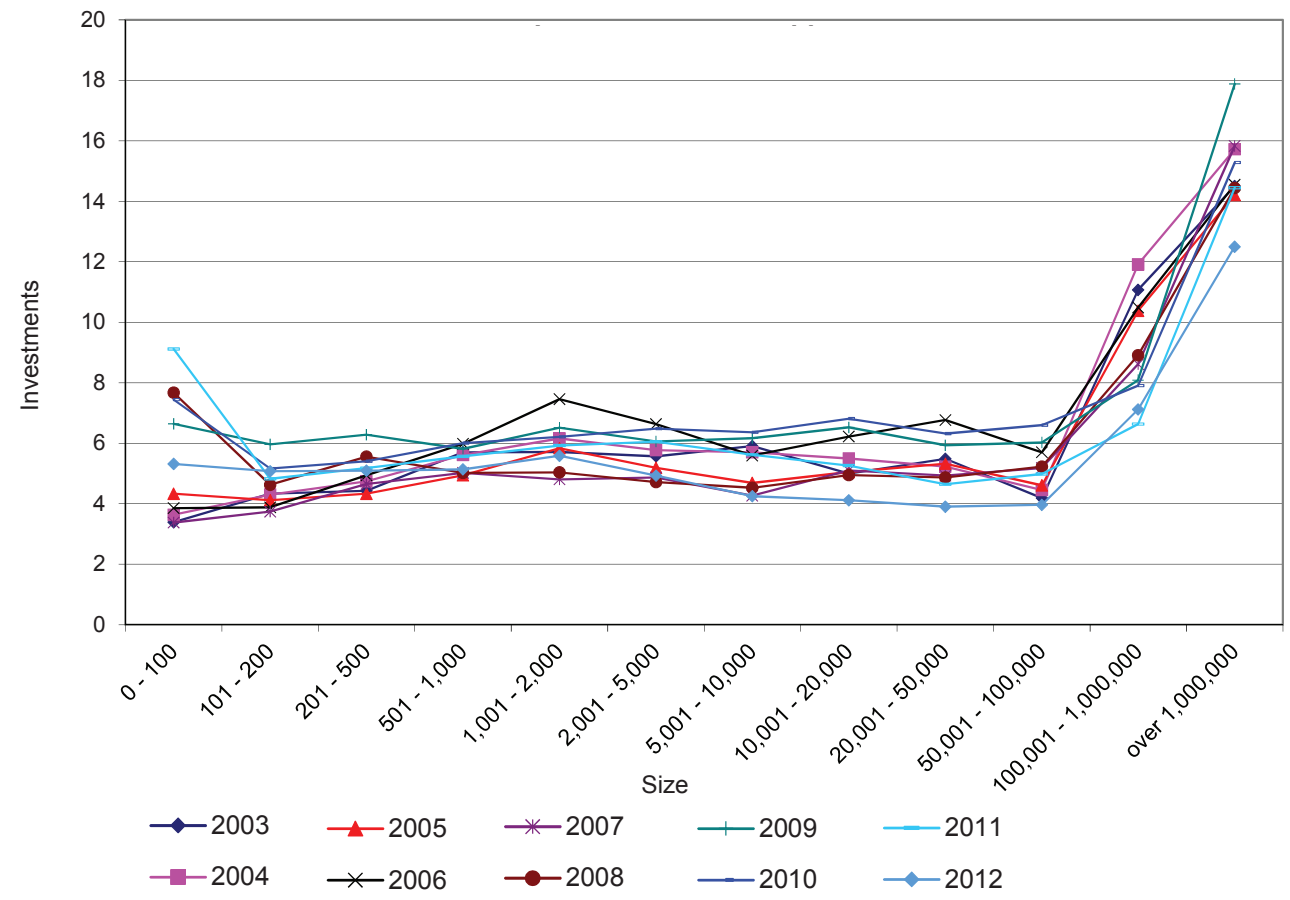

Source: authors.

How can be explained the clearly higher expenditures (per capita) on investments for these size categories of municipalities (towns) with over 50,000 residents? These municipalities have likely higher resource capacity towards implementation of investments at their disposal. The reason rests in the setup of parameters within the budgetary allocation of tax revenues. The given towns have also more experiences and possibilities to secure financial resources for implementation of public projects, both in the form of loans as well as obtaining resources through their co-financing (in particular from the EU funds). The City 
of Prague simultaneously fulfils the function of a region - in this sense it also participates on the budgetary revenues and ensures public services in other regions that are regionally provided (for example secondary education, health service, transport services, etc.).

Within a more detailed analysis of investments we find out that in election years there comes to a significant average difference in expenditures on investments. This finding supports also the analysis of a number of positive and negative differences in expenditures on investments in election and non-election years (Table 4).

Table 4 | Analysis of Positive and Negative Differences in Expenditures on Transfers and Investments in Election and Non-Election Years

\begin{tabular}{|l|c|c|c|c|}
\hline \multirow{2}{*}{ Monitored data } & \multicolumn{2}{|c|}{ Elections } & \multicolumn{2}{c|}{ Percentage of positive differences } \\
\cline { 2 - 5 } & non-election & election & non-election & election \\
\hline Sum. tran. elections + & 44 & 12 & 0.458333 & 0.500000 \\
\hline Sum. inv. elections + & 36 & 17 & 0.37500 & 0.708333 \\
\hline
\end{tabular}

Table 4 indicates the numbers of positive and negative differences. The number of nonelection data is 96 and the number of election data is 24 . The value in columns "Elections" indicates how many of election/non-election data on costs are higher than the corresponding moving average. From these data there was determined the percentage of positive differences that indicates in how many percents of data on costs are costs above average.

As from the data on percentages of positive differences evident, for transfers there is no significant difference between election and non-election years. For investments, however, the difference between non-election and election years becomes very clear. From the above given investigation it is possible to express an assumption that the political cycle may rather be expected for investments whereas this will not be the case for transfers. More precise answers to these questions will help to find out the correlation analysis. Its results are shown in Table 5.

Grey (and italics) marked values may be considered as statistically significant. For our investigation it is necessary to monitor values of the difference in investments and transfers depending on elections. The correlation coefficient of the difference between investments and elections takes the value of 0.317032 . This value is statistically significant and indicates a moderately strong linear dependence. We may observe that for investments there exists the political cycle. This means that along elections there come more investments. In the case of transfers the correlation coefficient reaches the value of 0.100916 . This value is not statistically significant. This confirms the hypothesis $H_{1}$ that within the pre-election year there comes to no significant changes in the volume of transfers. Therefore the relationship between elections and an increase in expenditures on transfers was not established.

When examining the influence of the size of a municipality and transfers and the size of a municipality and investments it was found out that the correlation coefficients are not statistically significant. Nevertheless, the effect of the size of a municipality was still subjected to an additional analysis in which we examined (separately for election and nonelection years) the impact of the size of a municipality on transfers and investments. Within non-election years (Appendix 1) there are correlation coefficients statistically insignificant, Pearson's correlation coefficient reaches the value of 0.084980 for transfers and the value 
of 0.055874 for investments. The data for election years (Appendix 2) showed a moderately strong linear relationship between the size of a municipality and transfers (Pearson's coefficient of 0.367483 ) and investments (Pearson's coefficient of 0.242804). The limiting factor in this finding is the small number of data analysed for the election years. More detailed results are provided within Appendix. Therefore we may observe that the size of a municipality has within elections an impact on the volume of transfers and investments (per capita). Therefore, the hypothesis $\mathrm{H}_{3}$ was not confirmed.

Table 5 | Results of Correlation Analysis

\begin{tabular}{|c|c|c|c|c|c|c|c|}
\hline \multirow[t]{2}{*}{ Variable } & \multicolumn{7}{|c|}{$\begin{array}{l}\text { Correlation (grants-elections) } \\
\text { Marked correlations are significant at the level } p<0.05000 \\
\mathrm{~N}=120 \text { (Complete cases omitted for missing data) }\end{array}$} \\
\hline & $\begin{array}{l}\text { Difference } \\
\text { inv. }\end{array}$ & $\begin{array}{c}\text { Difference } \\
\text { tran. }\end{array}$ & $\begin{array}{l}\text { Difference } \\
\text { inv. } \%\end{array}$ & $\begin{array}{c}\text { Difference } \\
\text { tran. \% }\end{array}$ & Index size & Elections & Year \\
\hline $\begin{array}{l}\text { Difference } \\
\text { investments }\end{array}$ & 1 & -0.12458 & 0.697616 & -0.3188 & -0.00245 & 0.317032 & -0.01231 \\
\hline $\begin{array}{l}\text { Difference } \\
\text { transfers }\end{array}$ & -0.12458 & 1 & -0.01424 & 0.901 & -0.00101 & 0.100916 & 0.007004 \\
\hline $\begin{array}{l}\text { Difference } \\
\text { investments (\%) }\end{array}$ & 0.697616 & -0.01424 & 1 & -0.00306 & $-7.6 \mathrm{E}-16$ & 0.214658 & 0.016926 \\
\hline $\begin{array}{l}\text { Difference } \\
\text { transfers (\%) }\end{array}$ & -0.3188 & 0.901 & -0.00306 & 1 & $4.08 \mathrm{E}-16$ & 0.078736 & 0.020061 \\
\hline $\begin{array}{l}\text { Index size of } \\
\text { municipality }\end{array}$ & -0.00245 & -0.00101 & $-7.6 \mathrm{E}-16$ & $4.08 \mathrm{E}-16$ & 1 & $-9.4 \mathrm{E}-18$ & $1.31 \mathrm{E}-16$ \\
\hline Elections & 0.317032 & 0.100916 & 0.214658 & 0.078736 & $-9.4 \mathrm{E}-18$ & 1 & 0.087039 \\
\hline Year & -0.01231 & 0.007004 & 0.016926 & 0.020061 & $1.31 \mathrm{E}-16$ & 0.087039 & 1 \\
\hline
\end{tabular}

Based on the previous results we establish that it does not make sense to perform a regression analysis with variables other than investments and election and non-election years. Within the regression analysis we have found out that for the quadratic regression (Appendix 5) and exponential regression (Appendix 4) the coefficients are insignificant. Significant coefficients are only for the linear regression (Appendix 3); however, coefficients of determination come out as minimal.

\section{Conclusions}

Analysis of expenditures of municipalities of the Czech Republic for the period 2003-2012 leads to the conclusion that also at the level of municipalities there is present the political business cycle. However, the political business cycle has (compared to the macroeconomic level) its peculiarities at the level of municipalities. These mainly arise due to the limited options of municipal politicians to use economic instruments to win electoral votes in elections. Municipal politicians use public investments and projects to win electoral votes. This is confirmed by the rising expenditures of municipalities on investments prior to elections. That is to say, public investments and projects are visible goods that potentially can significantly affect decision-making of voters in elections. This is also why municipal 
politicians "set the time" of handover of the projects to the public towards the period just prior to elections.

Municipal politicians are rational and pragmatic. Therefore they implement public projects as a manifestation of the "care of politicians about their citizens". Municipal politicians rationally assume that their voters are informed and pragmatic actors who know about the "care of politicians about their citizens" and therefore will vote for them.

Examination of per capita expenditures on investments yielded the finding that these expenditures are higher for the size groups of municipalities with over 50,000 residents. For other size categories they are not very different. This reality may be explained by the fact that towns (respectively groups of municipalities with over 50,000 residents) have higher disposable financial resources (higher per capita own revenues in their budgets and greater ability to raise resources for the co-financing of municipal projects).

Apart from grant entitlements, larger municipalities have a broader portfolio of debt financing options since in a contact with a bank they have a higher bargaining power as well as a broader range of assets with which they may guarantee their obligations.

Expenditures on transfers do not prior to elections significantly change. This finding may be interpreted in a way that politicians prefer investment projects that the potential electoral constituency the so-called clearly "see" while transfers are mostly used to cover current operating expenses of associations, athletes and other groups. For these may municipalities apply in the form of subsidies/grants in accordance to the established rules.

\section{Appendix}

Table 1 | Results of Dependence Analysis of a Municipal Size Index and Transfers and Investments in Non-Election Years

\begin{tabular}{|l|r|r|r|r|r|r|}
\hline \multirow{2}{*}{ Variable } & \multicolumn{5}{|c|}{$\begin{array}{c}\text { Correlation (transfers of an option) } \\
\text { N=96 (Complete cases omitted for missing data) } \\
\text { Summarise the condition: V3=0 }\end{array}$} \\
\cline { 2 - 8 } & Averages & Std. dev. & Year & Index size & $\begin{array}{c}\text { Difference } \\
\text { tran. }\end{array}$ & $\begin{array}{c}\text { Difference } \\
\text { inv. }\end{array}$ \\
\hline Year & 2007.375 & 3.054763 & 1.000000 & 0.000000 & 0.006413 & 0.007001 \\
\hline Index size & 6.500 & 3.470174 & 0.000000 & 1.000000 & -0.084980 & -0.055874 \\
\hline Difference tran. & -0.014 & 0.272635 & 0.006413 & -0.084980 & 1.000000 & -0.119167 \\
\hline Difference inv. & -0.094 & 0.573560 & 0.007001 & -0.055874 & -0.119167 & 1.000000 \\
\hline
\end{tabular}


Table 2 | Results of Dependency Analysis of a Municipal Size Index and Transfers and Investments in Election Years

\begin{tabular}{|c|c|c|c|c|c|c|}
\hline \multirow[t]{2}{*}{ Average } & \multicolumn{6}{|c|}{$\begin{array}{c}\text { Correlation (transfers elections) } \\
\text { Marked correlations are significant at the level } p<0.05000 \\
\mathrm{~N}=\mathbf{2 4} \text { (Complete cases omitted for missing data) } \\
\text { Summarise the condition: V3 = } 1\end{array}$} \\
\hline & Averages & Std. dev. & Year & $\begin{array}{l}\text { Index } \\
\text { of size }\end{array}$ & $\begin{array}{c}\text { Difference } \\
\text { tran. }\end{array}$ & $\begin{array}{l}\text { Difference } \\
\text { inv. }\end{array}$ \\
\hline Year & 2008.000 & 2.043016 & 1.000000 & 0.000000 & -0.056611 & -0.388176 \\
\hline Index of size & 6.500 & 3.526299 & 0.000000 & 1.000000 & 0.367483 & 0.242804 \\
\hline $\begin{array}{l}\text { Difference } \\
\text { tran. }\end{array}$ & 0.054 & 0.252515 & -0.056611 & 0.367483 & 1.000000 & -0.402419 \\
\hline Difference inv. & 0.371 & 0.506219 & -0.388176 & 0.242804 & -0.402419 & 1.000000 \\
\hline
\end{tabular}

Table 3 | Results of Linear Regression

\begin{tabular}{|c|c|c|c|c|c|c|}
\hline \multirow[t]{2}{*}{$N=120$} & \multicolumn{6}{|c|}{$\begin{array}{c}\text { Results of regression with dependent variable: difference inv (grants-elections) } \\
R=0.31703192, R 2=0.10050924, \text { Adj. } R 2=0.09288643, F(1,118)=13.185, p<0.00042, \\
\text { Std. dev. of estimate: } 0.56107\end{array}$} \\
\hline & $\mathbf{b}^{*}$ & Std. dev. (of $b^{*}$ ) & B & Std. dev. (of b) & $t(118)$ & p-value \\
\hline Abs. term & & & -0.093619 & 0.057264 & -1.63488 & 0.104740 \\
\hline Elections & 0.317032 & 0.087309 & 0.464955 & 0.128046 & 3.63116 & 0.000419 \\
\hline
\end{tabular}

Table4 | Results of Exponential Regression

\begin{tabular}{|c|c|c|c|c|c|c|}
\hline \multirow[t]{2}{*}{$N=120$} & \multicolumn{6}{|c|}{$\begin{array}{l}\text { Results of regression with dependent variable: difference inv (transfers elections) } \\
\qquad \begin{array}{l}R=0.31703192, R 2=0.10050924, \text { Adj. } R 2=0.09288643 \\
F(1,118)=13.185, p<0.00042, \text { Std. dev. of estimate: } 0.56107\end{array}\end{array}$} \\
\hline & $\mathbf{b}^{*}$ & Std. dev. (of $b^{*}$ ) & b & Std. dev. (of b) & $t(118)$ & $p$-value \\
\hline Abs. term & & & -0.364213 & 0.112468 & -3.23836 & 0.001561 \\
\hline$e^{* *} V_{3}$ & 0.317032 & 0.087309 & 0.270593 & 0.074520 & 3.63116 & 0.000419 \\
\hline
\end{tabular}




\begin{tabular}{|c|c|c|c|c|c|c|}
\hline \multirow[t]{2}{*}{$N=120$} & \multicolumn{6}{|c|}{$\begin{array}{l}\text { Results of regression with dependent variable: difference inv. (transfers elections) } \\
\qquad \begin{array}{l}R=0.31703192, R 2=0.10050924, A d j . \\
R 2=0.09288643\end{array} \\
F(1,118)=13,185, p<0.00042 \text {, Std. dev. of estimate: } 0.56107\end{array}$} \\
\hline & $\mathbf{b}^{*}$ & Std. dev. (of $b^{*}$ ) & b & Std. dev. (of b) & $t(118)$ & $p$-value \\
\hline Abs.term & & & -0.093619 & 0.057264 & -1.63488 & 0.104740 \\
\hline V3**2 & 0.317032 & 0.087309 & 0.464955 & 0.128046 & 3.63116 & 0.000419 \\
\hline
\end{tabular}

\section{References}

Alesina, A. (1987), "Macroeconomic Policy in a Two-Party System as a Repeated Game." The Quarterly Journal of Economics, Vol. 102, No. 3, pp. 651-678, http://dx.doi.org/10.2307/1884222

Alesina, A., Sachs, J. (1988), "Political Parties and the Business Cycle in the United States 1948-1984." Journal of Money Credit and Banking, Vol. 20, No. 1, pp. 63-82, http://dx.doi.org/10.2307/1992667

Alesina, A., Roubini, N. (1992), "Political Cycles in OECD Economies." Review of Economic Studies, Vol. 59, No. 4, pp. 663-688, http://dx.doi.org/10.2307/2297992

Brender, A., Drazen, A. (2005), "Political Budget Cycles in New Versus Established Democracies." Journal of Monetary Economics, Vol. 52, No. 7, pp. 1271-1295, http://dx.doi.org/10.1016/j.jmoneco.2005.04.004

Brechler, J., Geršl, A. (2011), "Political Legislation Cycle in the Czech Republic.” Institute of Economic Studies, Faculty of Social Sciences, Charles University in Prague. IES Working Paper, No. 21/2011.

Downs, A. (1998), "Political Theory and Public Choice."The Selected Essays of Anthony Downs. Vol. 1, MPG Kooks Ltd, Bodmin, Cornwall.

Drazen, A. (2000), “The Political Business Cycle after 25 Years.” NBER Macroeconomics Annual, Vol. 15, No. 1, pp. 75-117, http://dx.doi.org/10.2307/3585387

Drazen, A. (2001), "The Political Business Cycle After 25 Years," in Bernanke, B. S., Rogoff, K., eds., NBER Macroeconomics Annual 2000. Boston: MIT Press, pp. 75-198.

Hibbs, D. A. (1977), "Political Parties and Macroeconomic Policy." The American Political Science Review, Vol. 71, No. 4, pp. 1467-1487, http://dx.doi.org/10.2307/1961490

Janků, J. (2013), "The Political Business Cycle in the Czech Republic." Central European Review of Economic Issues. ER-CEREI, Vol. 16, pp. 121-130.

Lindbeck, A. (1976), "Stabilization Policy in Open Economies with Endogenous Politicians." The American Economic Review. Vol. 66, No. 2, pp. 1-19.

MacRae, D. (1977), "A Political Model of Business Cycle." Journal of Political Economy, Vol. 85, No. 2, pp. 239-264, http://dx.doi.org/10.1086/260561

Nemec, J., Ochrana, F., Pavel, J., Šagát, V. (2010), Kontrola ve veřejné správě (Audit in Public Administration). Prague: Wolters Kluwer. 
Nordhaus, W. (1975), "The Political Business Cycle." The Review of Economic Studies, Vol. 42, No. 2, pp. 169-190, http://dx.doi.org/10.2307/2296528

Novotná, V., Varyšová, T. (2014), "Solving of Economic Model Using Modern Methods," in Vision 2020, ed., Sustainable Growth, Economic Development, and Global Competitiveness. Valencia: IBIMA, 2014, pp. 1811-1821.

Pavel, J. (2013), Veřejné zakázky a efektivnost (Public Procurement and Efficiency). Prague: Ekopress.

Persson, T., Tabellini, G. (2003), The Economic Effects of Constitutions. What Do the Data Say. Cambridge: MIT Press.

Rogoff, K. (1990), "Equilibrium Political Budget Cycles." The American Economic Review, Vol. 80, No. 1, pp. 21-36.

Rogoff, K., Sibert, A. (1988), "Elections and Macroeconomic Policy Cycles." Review of Economic Studies, Vol. 55, No. 1, pp. 1-16, http://dx.doi.org/10.2307/2297526

Rosenberg, J. (1992), "Rationality and Political Business Cycle: The Case of Local Government." Public Choice, Vol. 73, No. 1, pp. 71 -81, http://dx.doi.org/10.1007/BF00142917

Shi, M., Svensson, J. (2006), “Political Budget Cycles: Do They Differ Across Countries and Why?" Journal of Public Economics, Vol. 90, No. 8-9, pp. 1367-1389, http://dx.doi. org/10.1016/j.jpubeco.2005.09.009

Sedmihradská, L., Haas, J., Kubík, R. (2011), "Political Business Cycle in Czech Municipalities." Prague Economic Papers, Vol. 20, No. 1, pp. 59-70, http://dx.doi.org/10.18267/j.pep.387

Slaný, A., Žák, M. (1999), Hospodářská politika (Economic Policy). $1^{\text {st }}$ Ed. Prague: C. H. Beck

Štiková, R. (2007), "Modely Politického Cyklu a jejich Testování na Podmínkách ČR. (Political Cycle Models and Their Testing within Conditions of the Czech Republic)." Institute of Economic Studies, Faculty of Social Sciences, Charles University in Prague. IES Working Paper, No. 18/2007.

Veiga, L. G., Veiga, F. J. (2007), "Political Business Cycles at the Municipal Level. "Public Choice, Vol. 131, No. 1-2, pp. 45-64, http://dx.doi.org/10.1007/s11127-006-9104-2

Vlach, J., Nemec, J. (2001), Verejné obstarávanie vo väzbe na korupciu a transparentnost'. (Public Procurement in Relation to Corruption and Transparency). Bratislava: Transparency International Slovensko.

Žák, M. (1998), “Politicko-ekonomický cyklus (The Political-economic Cycle)." Politická ekonomie, No. 4, pp. 471-480. 